\title{
THE IMPLEMENTATION OF OUTDOOR STUDY METHOD IN IMPROVING STUDENTS CRITICAL THINKING SKILLS IN SOCIAL STUDY
}

\author{
(A Classroom Action Research at Class VIII-J of SMPN 4 Cimahi)
}

\author{
Agam Muhamad Syahril*, Eded Termedi, Jupri \\ Department of Social Studies Education \\ Indonesia University Of Education \\ e-mail: amuhamadsyahril@gmail.com
}

\begin{abstract}
The background of this research was defined based on the issue that the researcher found in the process of social study which showed students with low critical thinking skills. The research aims to address the problem through the implementation of the outdoor study. The implementation of outdoor study was believed could be a proper learning method in developing students' critical thinking. The method used in this study was classroom action research. Indicators of critical thinking listed in this study were give simple descriptions with sub indicators of identifying or formulating questions, identifying the answers, arguments, and opinion by using their own ideas, commenting on the problem and appreciating others' opinion. Analyzing by using sub indicators of comprehending the findings, connected the findings with the materials, and identifying the problems. The conclusion was established by using sub indicators of giving solution to the existed problems, giving the
\end{abstract}

\section{INTRODUCTION}

Learning is made to reach an achievement that has been made, in the process of social learning forced to reach an aim in cognitive, affective and psychomotor aspect. Besides that students forced to increase their critical thinking ability, it is listed in the goal of social study according to Zubaedi (2012, Page. 289) on the second point mentioned that social study aims to increase the ability of critical thinking, problem solving, inquiry skills and social skills. This means with learning of social, students need to develop the ability of critical thinking because from it the students will be more better in learning the material.

According to Jhonson in Sapriya (2009, Page. 144) stated that critical thinking is a term that used for a reflective activity to achieve a goal that contains a beliefs and behaviour rational based on element of practical, reflective, rational, reliable and the action so defined that critical thinking is an ability to think reflectively and rational that is conclusion based on the materials and the problem emerged during the research. According to the findings, it was denoted that all aspects of the critical thinking indicators were successfully done. It could be seen from the improvement showed by the students in every cycle through the implementation of outdoor study. The connection between outdoor study and the improvement of students' critical thinking skills was the implementation of outdoor study method introduced the students to the contexts whilst in usual, students only learn through the books, so the outdoor study makes the learning more contextual and meaningful. Also, it could train students' critical thinking. The general conclusion was the implementation of outdoor study method could improve students' critical thinking skills in social study at class $8 \mathrm{~J}$ in SMPN 4 Cimahi.

Keywords: Critical Thinking in Social Study, Outdoor Study Method

focused on determining what is to be believed or practiced. Critical of students can be seen from the activity of thinking that stated by Angelo (Bachman, 2005, Page. 6) that. the analysis, synthesis, recognition of the problem and solution, as well as assessment.

Student should be able to against the challenges of the 21 st century, it is presented in the curriculum of instruction of the Ministry of education and culture social study (2017, Page. 3) that include skills in critical thinking, reasons of students need to have critical thinking skills described by Zamroni and Mahfouz (2009, Page. 23-29) with the argument: first, the more rapidly developing of Science and Technology. Second, the student is people power. Third, and more complex life. Fourth, the key in developing creativity. Fifth, the employment demand for more mature in critical thinking. With these arguments the students need to be trained as early as possible, training in critical thinking can be applied in a 
learning and one of the study which is capable to develop of is social study.

Social study demanding student more think critical because social is subject that are sourced from the surrounding environment, so that students will always study and critic any views and learned. Therefore the way learning of students need to be improved to develop critical thinking ability, through learning that built their own thinking and learning that makes students better understand material like inquiry then the students will further develop how learning that develop critical thinking ability.

From the result of observation still seen that critical thinking ability of students is relatively low, it can be seen from the behavior of student learning as a) students answer short, when the teacher gives questions with the opinion answers, they give a short answer but the answer should be of their own opinion, so that inquiries to the questions students are still lacking. b) students inconnect the content, the lack of ability of critical thinking students make students only receive the material which learned in books and at schools, not critiquing such material as it connects with the experience of students or give an example. c) focus students only to the Handbook, students tend to be based against the textbooks, but when identifying a material not all there in the Handbook answers, when answers are not found in the student handbook could not answer. d) students less in giving opinions, students tend to be less able to give their own opinion, when given the questions students will see the book directly from his position but did not find the answer when students are less able to respond. e) Less giving questions, when given the opportunity to ask students only silent, but when the teacher gives students the question looks unclear to the materials, that students just listen to the material from the teacher alone but less critiquing of such content.

Critical thinking ability of students can be developed with practice to solving problems or analyze something, but before that the students should understand the material that would become the basis of the analysis or problem, therefore it's worth learning more contextual with direct implementation into neighborhoods so students know how the problem occurred, and according to the Istianah (2013, Page. 45) that "to bring in the direction of learning can develop critical thinking and creative ability should depart from learning that make students "it can be applied by using the method of learning beyond the classroom

The explanation above is in line with the explanation of outdoor study according to Wibowo (in Jakiatin Nisa, 2015, Page. 8) is:
Outdoor learning it is one way how we increase the capacity study the child. Children can study in greater depth through objects at hand than if learned in class that has many limitations. Further, learning outside the classroom can help children to apply the knowledge. In addition, learning outside of the classroom is more challenging for students and bridging between theory in the book and the fact that there are in the field.

While according to Irawan (in Ginting, 2005, Page. 37). Approach to learning outside the classroom is an approach to learning that uses the atmosphere outside of the classroom as a learning situation at a variety of games as a medium transformation of the concepts presented in the study.

Method of learning outside the classroom train the students to search for information, data, facts, unearth problems, look for solutions and conduct cooperation among students to pick up a conclusion. By using the method of outdoor study, the level of ability to think students will be sharpened and by learning directly through the environment students will get the reference to factually with the collection of information in a real that would later be associated with the materials given by the teacher in the classroom. In addition to the critical thinking ability, students will also be honed skill in gathering information, understand the facts, and critical thinking itself. After that any stimulus to solve a problem that makes the students as a problem solver. It is in line with what was said by Rahmawati (2016, Page. 67) the teacher should avoid educational model "style bank" where students are only able to move in three ways, namely records-receiving - save. In this case the teacher should always create the atmosphere of creative learning, fun, and full of meaning. More explained again that the outdoor study is a method with more emphasis to students for active learning rather than just glued to the hearing and writing alone but any students contribute in the study felt directly, meaning that what is perceived by the students directly will be more meaningful. Connectedness of the critical thinking ability with the method of outdoor study is the method or strategy is a great way to hone critical thinking ability which is where students will observe things that happened directly in the environment as well as to analyze the circumstances seemed, as for the method of outdoor study according to Nisa (2015, Page. 4) invites students active in exploring the surrounding environment to achieve skills cognitive, affective and psychomotoric so have mastery of knowledge and skills. Cognitive skills such as the ability to 
think logically, critically, reason, resolve and found a causal relationship. This means that the method of outdoor study push students to be more sharpening critical thinking ability in. Therefore, the method of learning beyond the classroom is expected to enhance the critical thinking ability of students in the learning of social.

As for the problem is examined through the study of this Class Action is the first How to steps to improve critical thinking ability of students in social study learning by using learning methods outside of the classroom, both how the results of the application of the method of learning beyond the classroom to enhance the critical thinking ability of students in the learning of social?

\section{METHOD}

Research methods the research method used was class Act (Classroom Action Research). Research methods class act aims to improve the process of learning activities. It is also stated by Ebbut in Kunandar (2008, Page. 43) that research is the systematic study of class actions of educational practices for the implementation of the improvement effort by a group of teachers by performing actions in their reflection, based on learning about the results of such actions. In other research design used was the model developed by Kemmis \& Taggart (Wiriatmadja, 2009, Page. 6667) with the stages of planning, acting, observing, and reflecting. Research instrument used is the human instrument, observation sheets, sheets, interviews, field note, analysis and documentation. As for the collection of data was obtained from observation, interview, photos, documentation, studies and notes field. Next the researchers used a qualitative and quantitative data analysis, for the analysis of qualitative data with the reduction of the data, the presentation of data, verification, the conclusion and validity of data including the member check, saturation, triangulation, and expert opinion. With the subject of research grade VIII-J.

\section{RESULTS AND DISCUSSION}

In the planning stages of these researchers conduct discussions with the supervisor in the implementation of the plan of learning beyond the classroom methods either in the form of RPP as well as scenarios that will be carried out in the field and prepare the assessment tools used in the form of sheets of observation to assess critical thinking ability of the students, besides a researcher assisted by partners as an observer. The focus of the researchers in this study include the first application of the method of learning beyond the classroom, both critical thinking ability of students in the learning of social, the third student observations after the application of the method of learning beyond the classroom, the fourth student during the learning process may be seen from the aspect of ask, a fringe opinion, answer questions, argue, argue, refute, and conclude.

At this stage of implementation, the researcher performs three times a cycle. Each cycle is divided into two acts. For the first act of learning will be done in the classroom with the aim of deepening the material, the teacher would pass on basis of the material that would later be studied further outside the classroom. In the second action will tackle learning methods beyond the classroom with the students brought to the environment around the school and learning environment that is associated with the previous learning material. Then the continuity acts to be performed amounted to six action or six meetings.

At the first meeting in the first cycle of the researchers doing the study material to students to the basics of the theory on labor material more intelligible. Formerly the teacher asked the students to form groups and these groups will be used during the cycle continues. After giving a description of the material presented gives teachers the problem to students regarding employment for review and identification of joint group that will be presented to the class. The second meeting is the application of the method of outdoor study and a continuation of the discussion at the meeting material or actions first. Researcher invites students to learn outside of the classroom, which is in the neighborhood around the school and explaining the material by direct view or prove the material they learn in a book or in the class associated with the environment around the school so that the material will be more understanding of the unexplained and the continuation of a description of the material that needs to be the teachers give the students do that after that the findings obtained will be discussed and presented in front of the class.

In the second, there are two acts or the meeting anyway. At the first meeting of the teachers explain the material in detail regarding the improved quality and material of the Government's efforts in tackling the problems of employment. At this meeting the students assigned to identify the different articles on each group to discussed and described the results to other groups in front of the class. At the second meeting was conducted again the application of the method of outdoor study and return teacher invites students to outside the classroom to learn directly with environment around, things are different in application outdoor study at this meeting the teacher invites Parties the institution represented by the head of the junior school the country 4 Cimahi to give an opinion regarding the response of the Government in 
addressing the problem of employment, in particular in the field of education and policies that provided education. Next the students fill out a task that had previously been given a teacher with the school principal speaker and presented back to the class with a discussion group to criticize the opinions expressed-income students.

On the third cycle there are also two actions or meetings. At the first meeting of the teachers give the apply method of public speaking to the students with the aim of looking into critical students against the material presented and also provide an explanation in depth to the underlying materials that students learned about the material economic systems and a variety of economic systems. Next the teacher explained back material with the use of the media to make a match to the students. At a subsequent meeting of students returning awarded method of outdoor study and as always teachers explain the material with hook material with facts on the ground so that

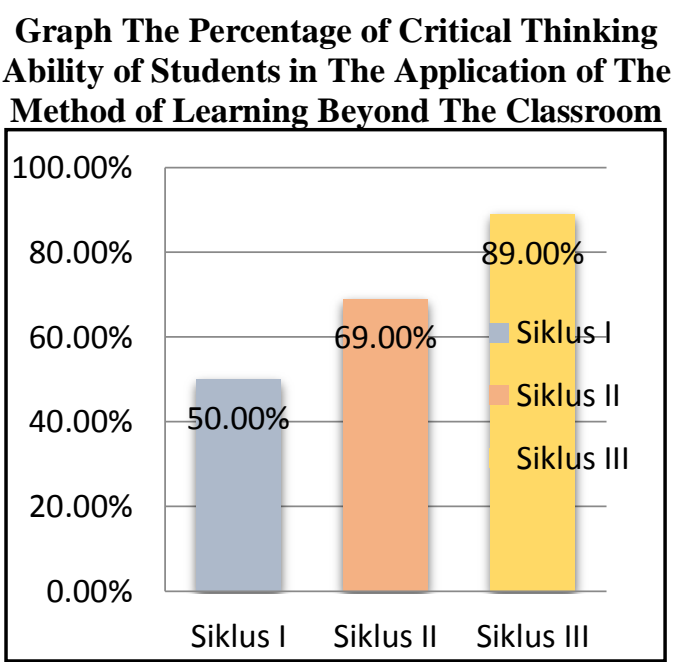

Based on the above graph can be known that the critical thinking ability of class VIII-J students has increased in each cycle. On first cycle earn a percentage of $50 \%$ this first cycle indicates that the critical thinking ability visible changes compared to when the researchers did a preliminary observation. Whereas, in the second cycle obtained the percentage of $69 \%$ and in the third cycle obtained the percentage of $89 \%$. An increase in every cycle proved that the application of the method of learning beyond the classroom can develop or enhance students ' critical thinking ability.

Analysis of researchers on the study that the method of learning beyond the classroom or often referred to by the method of outdoor study is one of the methods that can improve critical thinking ability of students. Santiningtyas (2012, more students can understand and criticize the material presented. Next the teacher catagorized to the students and identify the environment around schools, after which students give the results of his findings to other groups and discussed together to see student inquiries regarding the findings.

From the results obtained by cycle action researchers regarding the assessment of learning results is done using discussion, fact, as well as presentation during the process of learning activities, especially at the second meeting in each cycle. As for the indicators specified related critical thinking ability of students during learning by using the method of outdoor study as a treatment in overcoming problems experienced as giving an opinion or an argument with its own language, formulating questions, commenting on the issue, understand the results, linking results with material, identify the problem, appreciate the opinions of friends, provide solutions, and provides conclusions from the material or findings.
Page. 200) revealed that outdoor learning or outdoor study or outdoor activity based inquiry gives the opportunity to reconstruct on the students own knowledge by way of critical thinking and get real experience, so learning more meaningful. In the use this method to train teachers or familiarize students to hone critical thinking ability through methods of outdoor study by way of learning the nature of invention or inquiry so that the students themselves who develop thinking from the results of the findings obtained when learning, students are expected to bring up ideas from critical thinking after 
understanding directly what is being studied.

As explained earlier, that to apply the learning pool is the need for careful planning and implementation process that runs smoothly and focus more students to live out the learning process itself and more emphasis to meaningfulness. Planning-planning application was made and adapted to the objectives to be achieved as well as the material that is being lived is associated with later when students learn outside the classroom.

Social study learning students to always be critical with their surroundings because social is learning that the source comes from the environmental community and student environment itself, it is in line with the exposure Widodo (2016, Page. 12) "socioeconomic problems that developed in the community is the potential issues that can be used as a source of learning in learning social. This is because those issues sourced from neighbourhood learners so it is very appropriate for developing critical thinking ability learners ". This means that the demands of the students to be more critical of their surroundings because of the social has very extensive learning resources include environmental students and critical thinking ability in accordance with the objectives of social itself, through the method of outdoor study then students will exercise critical thinking ability directly, the outdoor study makes the students more familiar with the material to be studied due to learn directly, then the power analysis of students trained by looking at the phenomenon of the natural environment to compare and connect between the learning material is taught with what is seen in students outside the classroom, in terms of the method of outdoor study bridging the theory with the actual circumstances. After that the students were later expected to be more savvy and able to give opinions, arguments, rebuttal and questions as well as generalized a thing that's been learned by mengkontruksi the students thinking ability and critical the findings gained from the overall conclusion clearly, detailed, and valid.

\section{CONCLUSION}

Based on the results of the research action class that have done it can be concluded that students who previously had the ability to think critically low-after a PTK with treatment through the application of methods of learning beyond the classroom students ' critical thinking ability increases. The first time done learning steps, which include a part of planning researchers prepare any purpose to see critical thinking abilities of students through the method of outdoor study as preparing the RPP and reviewing KI and KD to be used so that with regards to competence. On implementation method of outdoor study applied with a wide variety of approaches that push students to improve critical thinking ability. Constraints and solutions for researchers can be explained that the constraints on natural tend towards how the maturity of planning or scenario of learning beyond the classroom are applied that are sometimes incompatible with the scenario created, therefore the solution given is the planning more researchers examine whether compliance with the later in the field or still need to be in the evaluation. Both the results of the application of the method of outdoor study to enhance the critical thinking ability of students of class VIII-a JUNIOR Home Affairs 4 Cimahi of good already it can be seen when the given method of learning beyond the classroom are able to be active in searching for information, collect information and analyze the information with connect, compare, assess, and generalize the results obtained. This means that the ability of critical thinking in students sharpened with learning given directly. Another benefit of the application of the method of learning beyond the classroom is the meaningfulness of a learning method of learning beyond the classroom to bridge between the existing theories in a book or a theory described by the teacher in the classroom with actual circumstances, thus avoiding problems of social is nomothetic.

For more obtain better results then the students often practice critiquing the phenomenonphenomenon around them that are associated with learning material and analyze the phenomenon or problem, more better it deliverd in the front of class.

\section{ACKNOWLEDGMENT}

Researcher would like say thanks to Mr. Dr. Dadang Sundawa, M.Pd as the Major of English Languange and . Mr. Drs. H. Eded Termedi, M.A as the Supervising Lecturer I, Drs. Jupri, MT, as the Supervising Lecturer II and Muhamad Iqbal, S.Pd, M.Si the support of the research that has been made.

\section{REFERENCES}

Bachman, E. (2005). Metode Belajar Berpikir Kritis dan Inovatif. Jakarta: PT Prestasi Pustaka Raya.

Ginting. (2005). Outdoor Learning. Bandung: P3GT.

Istianah, E. (2013). Meningkatkan Berpikir Kritis dan Kreatif Matematika dengan Pendekatan Model Elicting Activities (MEAS) pada Siswa SMA. Infinity Jurnal Ilmiah Program Studi Matematika STKIP 
Silinwangi Bandung, Vol. 2. No. 1, Hal. 43-54

Kementrian Pendidikan dan Budaya. (2017). Materi Bimbingan Teknis Kurikulum 2013. Jakarta: Depdiknas.

Kunandar. (2008). Langkah Mudah Penelitian Tindakan Kelas. Jakarta: Rajawali Pers.

Mahfudz, Z. \&. (2009). Panduan Teknis

Pembelajaran yang Mengembangkan Critical thinking. Jakarta: Depdiknas.

Nisa, J. (2015). Outdoor Learning Sebagai Metode Pembelajaran IPS dalam Menumbuhkan Karakter Peduli Lingkungan. Sosio Didaktika: Social study Education Journal Vol. 2 no. 1, April 2015. Diambil dari: http://journal.uinjkt.ac.id/index.php/SOSI O-FITK/article/download/1339/1602 (20 Januari 2017)

Rahmawati Isye, dkk. (2016). Pemanfaatan Lingkungan Sekitar Sebagai Sumber Pembelajaran Untuk Meningkatkan Kemampuan Berpikir Kritis. Gea: Jurnal Pendidikan Geografi. Vol. 16 no. 1, April 2016.

Santiningtyas, dkk. (2012). Pengaruh Outdoor Learning Berbasis Inkuiri Terhadap Hasil Belajar Materi Ekosistem. Unnes Journal of Biological. Vol. 1 no. 2 Agustus 2012. Diambil dari: Lib.unnes.ac.id/15669 (20 Januari 2017)

Sapriya. (2009). Pendidikan IPS: Konsep dan Pembelajaran. Bandung: PT. Remaja Rosdakarya.

Widodo, S. (2016). Pengembangan Keterampilan Berpikir Kritis Peserta Didik dengan Menggunakan Model Pembelajaran Berbasis Masalah (Problem Based Learning) Melalui Isu-Isu Sosial Ekonomi Pasca Penggenangan Waduk Jadigende dalam Pembelajaran IPS. International Journal Pedagogy of Social Studies. Vol. 1. No. 2. Hal. 12.

Wiriaatmadja, R. (2009). Metode Penelitian Tindakan Kelas: untuk Meningkatkan Kinerja Guru dan Dosen. Bandung: PT Remaja Rosdakarya.

Zubaedi. (2012). Desian Pendidikan Karakter: Konsepsi dan Aplikasi dalam Lembaga Pendidikan. Jakarta: Kencana Prenada Media Grup. 